\title{
DNA Damage in Lymphocytes in Hypertensive Subjects in Bangladesh
}

\author{
M. Saiedullah ${ }^{1,2 *}$, S. Hayat ${ }^{1,2}$, R. Zamir ${ }^{3}$, M. Arif ${ }^{4}$, Z.H. Howlader ${ }^{4}$, and M. Rahman ${ }^{4}$ \\ ${ }^{1}$ Department of Clinical Biochemistry, Bangladesh Institute of Health Sciences (BIHS) \& Hospital, \\ Mirpur, Dhaka, Bangladesh \\ ${ }^{2}$ Department of Applied Laboratory Sciences, Bangladesh University of Health Sciences (BUHS), \\ Mirpur, Dhaka, Bangladesh \\ ${ }^{3}$ Department of Chemistry, Bangladesh University of Health Sciences (BUHS), Mirpur, Dhaka, \\ Bangladesh \\ ${ }^{4}$ Department of Biochemistry and Molecular Biology, University of Dhaka, Dhaka, Bangladesh
}

Received 21 May 2013, accepted in final revised form 11 August 2013

\begin{abstract}
Oxidative stress due to imbalance between the production of reactive oxygen species and their dismutation is claimed to be higher in hypertensive subjects than normotensive subjects. In hypertensive subjects oxidative stress may damage deoxy-ribonucleic acids (DNA). In this study plasma superoxide dismutase (SOD) activities, protein carbonyl contents (PCCs) and extent of DNA damage in lymphocytes were measured in specimens obtained from 86 subjects to compare oxidative stress and oxidative DNA damage between normotensive and hypertensive subjects and to assess their relationship with the degree of blood pressure. Results were expressed as mean \pm SD. Two-tailed unpaired $t$ test and Pearson's correlation test were done to compare or to determine the relationship between groups or variables. SOD activities were $2.85 \pm 0.12 \mathrm{unit} / \mathrm{mg}$ protein and $3.84 \pm 0.45 \mathrm{unit} / \mathrm{mg}$ protein $(p<0.05)$ in hypertensive and normotensive groups respectively. PCCs were $4.77 \pm 0.36 \mathrm{nmol} / \mathrm{mg}$ protein and $3.75 \pm 0.23 \mathrm{nmol} / \mathrm{mg}$ protein in hypertensive and normotensive groups respectively. Olive tail moments (OTM) were $124.7 \pm 11.69$ units and 108.9 \pm 9.27 units in hypertensive and normotensive groups respectively. The correlation coefficient of OTM was $0.3924(p<0.05)$ for diastolic blood pressure and $0.3618(p<0.05)$ for systolic blood pressure. Oxidative stress and DNA damage was higher in hypertensives than normotensives and DNA damage correlated positively with blood pressure.
\end{abstract}

Keywords: Superoxide dismutase; Protein carbonyl content ; Oxidative stress; Oxidative DNA damage; Hypertension; Bangladeshi population.

๑) 2013 JSR Publications. ISSN: 2070-0237 (Print); 2070-0245 (Online). All rights reserved. doi: http://dx.doi.org/10.3329/jsr.v5i3.15022 J. Sci. Res. 5 (3), 535-543 (2013)

\section{Introduction}

During normal cellular metabolism, enzymatic reduction of molecular oxygen results in the formation of reactive oxygen species (ROS) such as hydroxyl radicals ( $\mathrm{OH}$ ),

\footnotetext{
*Corresponding author: md.saiedullah@gmail.com
} 
superoxide anions $\left(\mathrm{O}_{2}{ }^{-}\right)$, hypochlorous acids $(\mathrm{HOCl})$, lipid radicals and hydrogen peroxide $\left(\mathrm{H}_{2} \mathrm{O}_{2}\right)[1,2]$. These are physiologically important for health, but may be detrimental if present in excess quantities $[3,4]$. Oxidative stress, defined as the loss of balance between ROS production and antioxidant defense $[5,6]$ has been implicated in many pathophysiological conditions in the cardiovascular system including hypertension and heart failure, hypercholesterolemia, diabetes mellitus etc. [7]. Several untoward events like oxidative modification of deoxy-ribonucleic acids (DNA), lipid oxidation, modification of proteins and activation of redox sensitive genes may occur as a consequence of oxidative stress [8]. Activated oxygen and agents that generate oxygen free radicals and ionizing radiation induce numerous lesions in DNA that cause deletions, mutations and other lethal genetic effects. Characterization of this damage to DNA has indicated that both the sugar and the base moieties are susceptible to oxidation, causing base degradation, single strand breakage, and protein cross-linking $[9,10]$. Degradation of the base may produce 8-hydroxyguanine, hydroxymethyl urea, urea, thymine glycol, thymine and adenine ring-opening and saturated products. Oxidative stress also inactivates the human DNA mismatch repair system [11]. Since protein carbonyl group contents are used as indicators of oxidative stress, their evaluation in plasma/serum serves as a marker of free radical activity [12]. In addition, superoxide dismutase (SOD) is thought to play a major role in the first line of antioxidant defense by catalyzing the dismutation of $\mathrm{O}_{2}^{-}$to molecular oxygen $\left(\mathrm{O}_{2}\right)$ and $\mathrm{H}_{2} \mathrm{O}_{2}$, which can be converted to nontoxic compounds via catalase (CAT) and glutathione peroxidase [13]. Therefore, the measurement of protein carbonyl group contents and SOD activity in plasma/serum, provide the endogenous antioxidant status and oxidative stress. A simple, sensitive and rapid method for detecting DNA damage is the comet assay [14]. The detrimental effect of increased oxidative stress on DNA $[15,16]$ can be measured by comet assay. It can be used to estimate DNA damage at the individual cell level through strand breaks, open repair sites, cross-links and alkali labile sites generated from oxidative stress [14, 17]. DNA damage in lymphocytes may also occur in coronary artery diseases (CAD) and inflammation $[18,19]$.

It is claimed that hypertension is associated with decreased antioxidant capacity [20, 21], increased production of ROS [22] and DNA damage. ROS occurs more frequently in hypertensive subjects than in normotensives [23-25]. A recent study in Chinese Han adults showed that oxidative stress is a reliable risk factors for developing hypertension [26]. Oxidative stress is influenced by environmental factors and may partly be associated with racial variation [27]. In this study our objective was to determine the endogenous antioxidant status, extent of oxidative DNA damage and to determine their relationship with the degree of hypertension in a Bangladeshi population.

\section{Experimental}

\subsection{Study type, setting and time}

This case-control study was carried out in the Department of Biochemistry \& Molecular Biology, Dhaka University, Bangladesh during the period of January 2008 to December 2008. 


\subsection{Study subjects}

A total of 86 adult nonmedicated normotensive and hypertensive (male and female) subjects who were free from other known diseases were studied after an overnight fast at the Hypertension Centre, Green Road, Dhaka. Hypertension was defined on the basis of elevated blood pressure readings found repeatedly to be $>140 / 90 \mathrm{~mm} \mathrm{Hg}$. Verbal consent was taken from the subjects before collection of anthropometric data and specimens.

\subsection{Specimen collection}

Blood specimens were collected in ethylenediaminetetraacetic acid (EDTA)-containing tubes (BD vacutainer ${ }^{\circledR}$ containing $3.6 \mathrm{mg} \mathrm{K}{ }_{2}$ EDTA; BD, Franklin Lakes, NJ USA) after overnight fasting. Plasma was separated and used to measure SOD activities and protein carbonyl contents. Lymphocytes were isolated using Histopaque and were then used in the comet assay.

\subsection{Superoxide dismutase assay}

The SOD assay was performed with slight modification of the method described by Beauchamp et al [28]. In this assay procedure, the reaction mixture contained $1.1 \mathrm{~mL}$ of $59 \mathrm{mM}$ phosphate buffer ( $\mathrm{pH} 7.4$ ), $75 \mu \mathrm{L}$ of $20 \mathrm{mM}$ methionine, $40 \mu \mathrm{L}$ of $1 \%$ triton $\mathrm{x}$ $100,75 \mu \mathrm{L}$ of $10 \mathrm{mM}$ HAC (hydroxyl amine hydrochloride), $100 \mathrm{~mL}$ of $78 \mu \mathrm{M}$ EDTA and $100 \mu \mathrm{L}$ of plasma. The reaction was started by the addition of $80 \mu \mathrm{L}$ of freshly prepared $40 \mu \mathrm{M}$ riboflavin. After the addition of riboflavin, the tubes were placed under fluorescent light for 10 minutes. Then $1 \mathrm{~mL}$ of Griess reagent was added to each tube. The optical density was measured at $543 \mathrm{~nm}$ after 10 minutes and compared with the controls, which were kept under dark conditions. The results were expressed as nmol SOD/mg protein.

\subsection{Estimation of protein carbonyl contents}

Protein carbonyl contents in plasma were analyzed by 2, 4-dinitrophenylhydrazine (DNPH) method as described by Levine et al [29]. The reaction mixture contained $40 \mu \mathrm{L}$ of plasma mixed with $900 \mu \mathrm{L}$ of $10 \mathrm{mM}$ DNPH in $2 \mathrm{~N} \mathrm{HCl}$. Blank was prepared by adding only $2 \mathrm{~N} \mathrm{HCl}$. Samples were then incubated in dark place for 1 hour at room temperature, vortexed every 10-15 minutes, precipitated with 30\% TCA (final concentration) and centrifuged for 3 minutes at 12,000 rpm. The pellet was washed three times with $1 \mathrm{~mL}$ ethanol:ethyl acetate $(1: 1, \mathrm{v} / \mathrm{v})$ to remove excess DNPH and resolved in $1.5 \mathrm{~mL} 10 \% \mathrm{SDS}$ at $37^{\circ} \mathrm{C}$ for $\sim 1$ hour. Insoluble substances were removed by centrifugation at 12,000 rpm for 3 minutes. The difference in absorbance between the DNPH-treated and HCl-treated samples was determined at $360 \mathrm{~nm}$ and the results were expressed as nmol carbonyl groups $/ \mathrm{mg}$ protein using the extinction coefficient of $22.0 \mathrm{mM}^{-1} \mathrm{~cm}^{-1}$. Total protein content 
in the plasma was estimated by Hartee Lowry assay method. The plasma was incubated at $50^{\circ} \mathrm{C}$ for 10 minutes in $1 \mathrm{~N} \mathrm{NaOH}$ (final concentration). After cooling at room temperature for 10 minutes, solution was then treated with alkaline copper reagent to produce protein$\mathrm{Cu}^{2+}$ complex, which in turn reduced the Folin-Ciocalteau reagent and generated blue colored complex. The absorption of the complex was then measured against standard solution of bovine serum albumin (BSA) at $650 \mathrm{~nm}$ by spectrophotometer.

\subsection{Comet assay}

The comet assay was carried out according to the protocol described by Tice et al [14] with slight modification. Lymphocytes were suspended in $0.7 \%$ low-melting-point agarose in phosphate buffered saline (PBS) at $37^{\circ} \mathrm{C}$ and placed on microscopic slide with a layer of $1 \%$ agarose. The slides were immersed in lysis solution at $4^{\circ} \mathrm{C}$ for 1 hour to remove cellular membranes, proteins and so forth. Slides were then placed in a single row in a horizontal electrophoresis tank containing alkaline buffer at $4^{\circ} \mathrm{C}$ for 20 minutes for DNA unwinding. After 20 minutes, the current was switched on and electrophoresis was carried out at $25 \mathrm{~V}, 300 \mathrm{~mA}$ for 40 minutes at the same temperature. Following removal of slides from lysis solution, the slides were washed three times (5 minutes for each wash) with neutralization buffer. Subsequently the slides were visualized by silver staining as described by Nadin et al [30]. All the steps were conducted under yellow light to minimize the possibility of cellular DNA damage. Slides were analyzed microscopically by using software called Computer Assay Software Project (CASP, version 1.2.2). Threshold values of CASP parameters were adjusted to obtain the optimal values for our staining protocol. The selected parameters were: Head center threshold $($ HCT $)=0.999$, Comet threshold $(\mathrm{CT})=0.005$, Head threshold $(\mathrm{HT})=0.05$, Tail threshold $(\mathrm{TT})=0.05$ and profile 1 . The comet parameters analyzed by CASP were: length of head and length of tail of comet (in pixels), \% of DNA in the comet's head and in the tail, the tail moment (arbitrary units) and olive tail moment (arbitrary units). The Olive tail moment $(\mathrm{OTM})$ is [percent of DNA in the tail] $\times$ [distance between the center of gravity of DNA in the tail and that of center of gravity of DNA in the head in $\mathrm{x}$-direction].

\subsection{Statistical analysis}

Data were expressed as mean \pm standard deviations. Unpaired two-tailed $t$ test was used to compare variables between case and control and Pearson's correlation test was used to evaluate the relationship between variables. GraphPad Prism version 5.04 for Windows was used for statistical analysis.

\section{Results}

\subsection{Clinical characteristics of the study subjects}

The clinical characteristics of the study subjects are shown in Table 1. Participants were matched for age and sex. There was no significant difference in body mass index (BMI) 
between normotensive and hypertensive groups. Both systolic blood pressure (SBP) and diastolic blood pressure (DBP) were significantly higher in hypertensive group than in normotensive group (SBP: $145.3 \pm 18.8 \mathrm{~mm} \mathrm{Hg}$ vs $116.6 \pm 14.1 \mathrm{~mm} \mathrm{Hg}, p<0.01$; DBP: $103.4 \pm 18.8 \mathrm{~mm} \mathrm{Hg}$ vs $76.2 \pm 15.6 \mathrm{~mm} \mathrm{Hg}, p<0.001)$.

Table 1. Clinical characteristics of normotensive and hypertensive subjects.

\begin{tabular}{lccl}
\hline & $\begin{array}{l}\text { Normotensive } \\
(n=40)\end{array}$ & $\begin{array}{l}\text { Hypertensive } \\
(n=46)\end{array}$ & $p$ value \\
\hline Gender (male/female) & $23 / 17$ & $26 / 20$ & \\
Age (year) & $38.2 \pm 4.60$ & $40.5 \pm 5.0$ & $\mathrm{NS}$ \\
BMI $\left(\mathrm{Kg} / \mathrm{m}^{2}\right)$ & $24.4 \pm 2.19$ & $26.2 \pm 1.81$ & $\mathrm{NS}$ \\
SBP $(\mathrm{mm} \mathrm{Hg})$ & $116.6 \pm 14.1$ & $145.3 \pm 18.8$ & $<0.01$ \\
DBP $(\mathrm{mm} \mathrm{Hg})$ & $76.2 \pm 15.6$ & $103.4 \pm 18.8$ & $<0.001$ \\
\hline
\end{tabular}

Data are expressed as mean \pm SD (standard deviation); BMI, body mass index; SBP, systolic blood pressure; DBP, diastolic blood pressure; NS, not significant

\subsection{Endogenous antioxidant status}

The endogenous antioxidant status was assessed by measuring SOD. In hypertensive subjects, SOD activity was significantly lower $(2.85 \pm 0.12$ units/mg protein) compared to that of normotensive controls (3.84 \pm 0.45 units/mg protein; $p<0.05$; Fig. 1A).

A

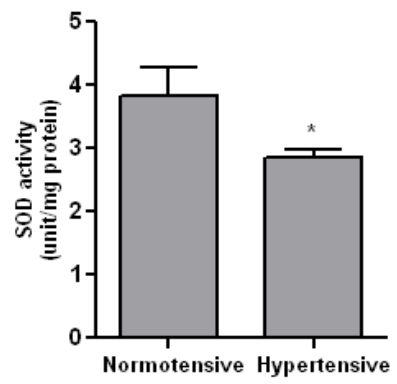

B

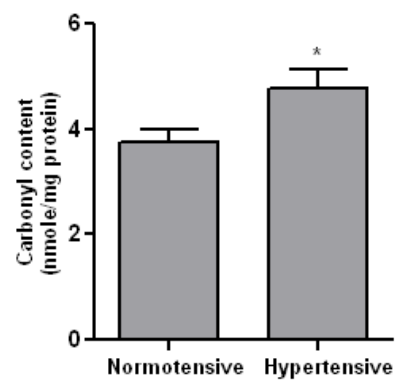

Fig. 1. Comparison of plasma SOD activity (A) and plasma protein carbonyl content (B) between hypertensive and normotensive subjects $(*, p<0.05)$.

\subsection{Oxidative stress}

Protein carbonyl group content was determined to assess the extent of oxidative stress. It was found significantly higher in hypertensive subjects $(4.77 \pm 0.36 \mathrm{nmol} / \mathrm{mg}$ protein $)$ than that of normotensive $(3.75 \pm 0.23 \mathrm{nmol} / \mathrm{mg}$ protein; $p<0.05$; Fig. $1 \mathrm{~B})$. 


\subsection{DNA damage}

Comet images of lymphocytes from hypertensive subjects showed abnormal appearances (long tailed nucleus; Fig. 2B) whereas, in the normotensive subjects, there was no such evidence of comet formation (Fig. 2A). The extent of DNA damage can be expressed by measuring the percent of DNA present in the tail region by comet analysis. Tailed DNA was significantly higher in the hypertensive group than that of normotensive controls (6.74 \pm 1.03 units vs $5.35 \pm 1.04$ units, $p<0.05$; Fig. 2 C). The tail moment (percent tail DNA $\times$ tail length), a commonly used marker of DNA damage, was significantly higher in hypertensive subjects than that of normotensive controls $(124.7 \pm 11.69$ units vs 108.9 \pm 9.27 units, $p<0.01$; Fig. 2D). The correlation coefficient of SOD, PCC and OTM with blood pressure is presented in Table 2.
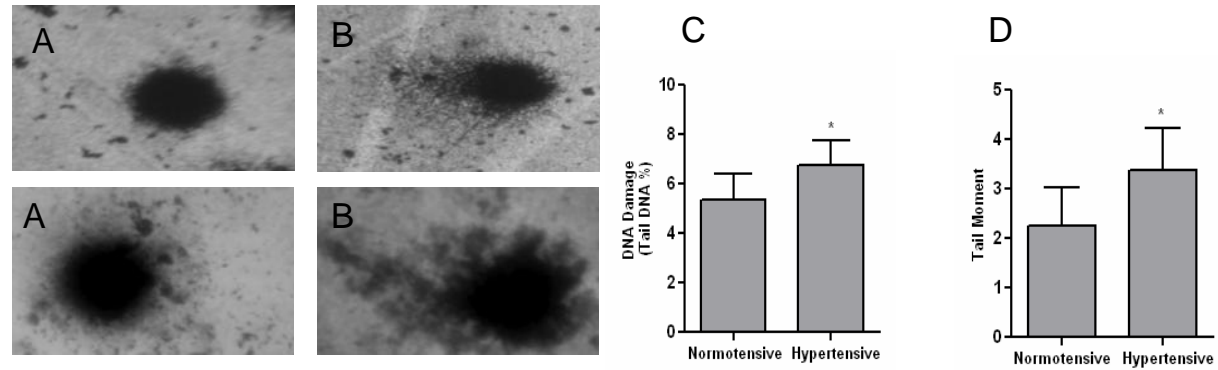

Fig. 2. Comet images of lymphocytes from normotensive subjects (A) and hypertensive subjects (B), and comparison of tailed DNA (\%) (C) and Olive tail moment (D) between normotensive and hypertensive subjects $(*, p<0.05)$.

Table 2. Relationship of oxidative stress and oxidative DNA damage with blood pressure.

\begin{tabular}{lcccc}
\hline \multirow{2}{*}{ Parameters } & \multicolumn{2}{c}{ Diastolic blood pressure } & \multicolumn{2}{c}{ Systolic blood pressure } \\
\cline { 2 - 5 } & $r$ value & $p$ value & $r$ value & $p$ value \\
\hline SOD & -0.3490 & $<0.05$ & -0.3207 & $<0.05$ \\
PCC & 0.4381 & $<0.01$ & 0.4565 & $<0.01$ \\
OTM & 0.3924 & $<0.05$ & 0.3618 & $<0.05$ \\
\hline
\end{tabular}

SOD = Superoxide dismutase activities $; \mathrm{PCC}=$ Protein carbonyl contents; $\mathrm{OTM}=$ Olive tail moment.

\section{Discussion}

The association of oxidative stress and hypertension was described in many studies [26, $31,32]$. Oxidative stresses not only enhance the degree of hypertension but also cause 
damage to cellular DNA. In this study, antioxidant status as assessed by SOD activity, oxidative stress as assessed by protein carbonyl content and DNA damage as determined by comet assay in blood specimens obtained from adult Bangladeshi subjects were evaluated. Relationship of antioxidant status, oxidative stress and DNA damage with the degree of hypertension were also examined.

We found a reduced SOD activity in the hypertensive subjects (Fig. 1A) compared to normotensive controls. This finding is consistent with the findings of other studies [21, 33]. Reduced total antioxidant status (TAS) in hypertensive subjects compared to normotensive subjects has also been reported by some studies [25, 34]. On evaluating the protein carbonyl content, we found a higher oxidative stress in hypertensive subjects (Fig. 1B) than normotensive controls. The increased protein carbonyl content in hypertensive subjects is consistent with the reduced SOD activity in plasma. This result indicates the excessive bioavailability of ROS. Physiologically, ROS are produced in a controlled manner at low concentrations and act as signaling molecules [35] to maintain vascular integrity by regulating endothelial function and vascular contraction-relaxation. But, under pathological conditions, decreased bioavailability of SOD leads to increased ROS bioactivity that leads to endothelial dysfunction.

Increased oxidative stress may initiate lipid peroxidation in cell membranes, damage to membrane proteins or may cause DNA damage. It is well-documented that DNA damage frequently occurs in cells exposed to oxidative stress [15]. In this study, comet analysis showed that the normotensive controls had compact DNA and maintained the circular form of a normal nucleus, without any evidence of comet formation (Fig. 2A). In contrast, lymphocytes from hypertensive subjects exhibited a distorted appearance, indicating substantial DNA damage (Fig. 2B) that may be due to oxidative stress. This result is consistent with the comet analysis of other studies [25, 34, 36, 37]. It is also consistent with the findings of other studies [23, 24, 31], where DNA damage was assessed by 8 hydroxy-2'-deoxyguanosine (8-OHdG) - another marker of oxidative DNA damage [10]. Furthermore, we found a significant positive correlation between blood pressure and Olive tail moment (Table 2). As reduced level of antioxidant enzymes is associated with the increased levels of oxidative DNA damage [21, 38], our findings indicate increased oxidative stress and lymphocyte DNA damage in hypertensive subjects in Bangladeshi population.

A recent report observed a reduced TAS activity and increased lymphocyte DNA damage in newly diagnosed essential hypertensive subjects. Significant improvement of TAS and DNA damage was found after one year treatment with carvediol. [25]. This may be due to the inherent antioxidative property of carvediol [24]. Decreased TAS and increased lymphocyte DNA damage has also been reported in subjects with white-coat hypertension [34]. Moreover, another recent study on Chinese Han adults [26] concluded that oxidative stress as assessed by plasma reactive carbonyl species (RCS) is a reliable risk factor for developing hypertension. Since there is an upward trend in the prevalence of hypertension in Bangladesh [39], our results may provide additional information for the 
management of hypertension by evaluating oxidative stress and oxidative DNA damage in hypertensive subjects in Bangladeshi population.

\section{Conclusion}

This study reveals that endogenous antioxidant is lower, and the oxidative stress and the extent of oxidative DNA damage are higher in hypertensive subjects than in normotensive subjects and DNA damage is positively related to blood pressure.

\section{References}

1. B. M. Babior, Am. J. Med. 109, 33 (2000). http://dx.doi.org/10.1016/S0002-9343(00)00481-2

2. K. Hensley, K. A. Robinson, S. P. Gabbita, S. Salsman, and R. A. Floyd, Free Radic. Biol. Med. 28,1456 (2000). http://dx.doi.org/10.1016/S0891-5849(00)00252-5

3. S. Palanduz, E. Ademoglu, C. Gokkusu, and S. Tamer, Res. Commun. Mol. Pathol. Pharmacol. 109, 309 (2001).

4. E. M. Mills, K. Takeda, Z. X. Yu, V. Ferrans, Y. Katagiri, H. Jiang, M. C. Lavigne, T. L. Leto, and G. Guroff, J. Biol. Chem. 273, 22165 (1998). http://dx.doi.org/10.1074/jbc.273.35.22165

5. E. Dursun, T. Ozben, G. Suleymanlar, B. Dursun, and G. Yakupoglu, Clin. Chem. Lab. Med. 40, 1009 (2002). http://dx.doi.org/10.1515/CCLM.2002.175

6. A. Klemm, C. Voigt, M. Friedrich, R. Funfstuck, H. Sperschneider, E. G. Jager, and G. Stein, Nephrol. Dial. Transplant. 16, 2166 (2001). http://dx.doi.org/10.1515/CCLM.2002.175

7. D. G. Harrison, Clin. Cardiol. 20, 11 (1997).

8. R. P. Patel, D. Moellering, J. Murphy-Ullrich, H. Jo, J. S. Beckmann, and V. M. Darley-Usmar, Free Radic. Biol. Med. 28, 1780 (2000). http://dx.doi.org/10.1016/S0891-5849(00)00235-5

9. J. A. Imlay and S. Linn. Science 240,1302 (1988). http://dx.doi.org/10.1126/science.3287616

10. M. K. Shigenaga and B. N. Ames. Free Radic. Biol. Med. 10, 211 (1991). http://dx.doi.org/10.1016/0891-5849(91)90078-H

11. C. L. Chang, G. Marra, D. P. Chauhan, H. T. Ha, D. K. Chang, L. Ricciardiello, A. Randolph, J. M. Carethers, and C. R. Boland, Am. J. Physiol. Cell. Physiol. 283, 148 (2002). http://dx.doi.org/10.1152/ajpcell.00422.2001

12. S. Garibaldi, I. Aragno, P. Odetti, and U. M. Marinari, Biochem. Mol. Biol. Int. 34, 729 (1994).

13. G. Benzi, A. Moretti, Neurobiol. Aging 16, 661 (1995). http://dx.doi.org/10.1016/01974580(95)00066-N

14. R. R.Tice, E. Agurell, D. Anderson, B. Burlinson, A. Hartmann, H. Kobayashi, Y. Miyamae, E. Rojas, J. C. Ryu, and Y. F. Sasaki, Environ. Mol. Mutagen. 35, 206 (2000). http://dx.doi.org/10.1002/(SICI)1098-2280(2000)35:3<206::AID-EM8>3.0.CO;2-J

15. B. Halliwell and O. I. Aruoma, FEBS (Lett.) 281, 9 (1991). http://dx.doi.org/10.1016/0014-5793(91)80347-6

16. B. N. Ames, Free Radic. Res. Commun. 17, 121 (1989). http://dx.doi.org/10.3109/10715768909087933

17. A. Hartmann, E. Agurell, C. Beevers, S. Brendler-Schwaab, B. Burlinson, P. Clay, A. Collins, A. Smith, G. Speit, V. Thybaud, and R. R. Tice, Mutagenesis 18, 45 (2003). http://dx.doi.org/10.1093/mutage/18.1.45

18. N. Botto, A. Rizza, M. G. Colombo, A. M. Mazzone, S. Manfredi, S. Masetti, A. Clerico, A. Biagini, and M. G. Andreassi, Mutat. Res. 493, 23 (2001).

http://dx.doi.org/10.1016/S1383-5718(01)00162-0

19. D. Schottenfeld and J. Beebe-Dimmer, CA Cancer J. Clin. 56, 69 (2006). http://dx.doi.org/10.3322/canjclin.56.2.69

PMid:16514135 
20. C. Russo, O. Olivieri, D. Girelli, G. Faccini, M. L. Zenari, S. Lombardi, and R. Corrocher, J. Hypertens. 16, 1267 (1998). http://dx.doi.org/10.1097/00004872-199816090-00007

21. L. Zhou, W. Xiang, J. Potts, M. Floyd, C. Sharan, H. Yang, J. Ross, A. M. Nyanda, and Z. Guo, Free Radic. Biol. Med. 41, 1384 (2006). http://dx.doi.org/10.1016/j.freeradbiomed.2006.07.019

22. P. S. Prabha, U. N. Das, R. Koratkar, P. S. Sagar, and G. Ramesh, Prostaglandins Leukot. Essent. Fatty Acids 41, 27 (1990). http://dx.doi.org/10.1016/0952-3278(90)90127-7

23. H. Negishi, K. Ikeda, S. Kuga, T. Noguchi, T. Kanda, M. Njelekela, L. Liu, T. Miki, Y. Nara, T. Sato, Y. Mashalla, J. Mtabaji, and Y. Yamori, J. Hypertens. 19, 529 (2001). http://dx.doi.org/10.1097/00004872-200103001-00002

24. J. Lee, M. Lee, J. U. Kim, K. I. Song, Y. S. Choi, and S. S. Cheong, Hypertension 45, 986 (2005). http://dx.doi.org/10.1161/01.HYP.0000164569.63160.24

25. P. Subash, K. Premagurumurthy, A. Sarasabharathi, and K. M. Cherian, J. Hum. Hypertens. 24, 475 (2010). http://dx.doi.org/10.1038/jhh.2009.100

26. K. Chen, F. Xie, S. Liu, G. Li, Y. Chen, W. Shi, H. Hu, L. Liu, and D. Yin, Free Radic. Res. 45, 568 (2011). http://dx.doi.org/10.3109/10715762.2011.557723

27. D. L. Feairheller, J. Y. Park, K. M. Sturgeon, S. T. Williamson, K. M. Diaz, P. Veerabhadrappa, and M. D. Brown, Clin. Trans. Sci. 4,32 (2011). http://dx.doi.org/10.1111/j.1752-8062.2011.00264.x

28. P. C. Beauchamp and I. Fridovich, Anal. Biochem. 44, 276 (1971). http://dx.doi.org/10.1016/0003-2697(71)90370-8

29. R. L. Levine, J. A. Williams, E. R. Stadtmann, E. Shacter, Methods Enzymol. 233, 346 (1994). http://dx.doi.org/10.1016/S0076-6879(94)33040-9

30. S. B. Nadin, L. M. Vargas-Roig, and D. R. Ciocca, J. Histochem. Cytochem. 49, 1183 (2001). http://dx.doi.org/10.1177/002215540104900912

31. H. Negishi, M. Njelekela, K. Ikeda, M. Sagara, T. Noguchi, S. Kuga, T. Kanda, L. Liu, Y. Nara, M. Tagami, and Y. Yamori, Hypertens. Res. 23, 285 (2000). http://dx.doi.org/10.1291/hypres.23.285

32. R. Saraswathi, D. Sankar, A. Ali, Y. Uehara, S. Abe, G. Sambandam, and M. R. Rao, Clin. Exp. Hypertens. 33, 437 (2011). http://dx.doi.org/10.3109/10641963.2010.549259

33. J. Redón, M. R. Oliva, C. Tormos, V. Giner, J. Chaves, A. Iradi, and G. T. Sáez, Hypertension 41,1096 (2003). http://dx.doi.org/10.1161/01.HYP.0000068370.21009.38

34. A. Yildiz, M. Gür, R. Yilmaz, R. Demirbağ, H. Celik, M. Aslan, and A. Koçyiğit, Arch. Turk. Soc. Cardiol. 36,31 (2008).

35. R. M. Touyz, F. Tabet, and E. L. Schiffrin, Clin. Exp. Pharmacol. Physiol. 30, 860 (2003). http://dx.doi.org/10.1046/j.1440-1681.2003.03930.x

36. M. Gur, A. Yildiz, R. Demirbag, R. Yilmaz, A. Koçyigit, H. Celik, and N. Aksoy, Clin. Biochem. 40, 454 (2007). http://dx.doi.org/10.1016/j.clinbiochem.2006.10.024

37. M. Gür, Z. Elbasan, D. Y. Şahin, N. Y. Koyunsever, T. Seker, B. Ozaltun, M. Caylı, and A. Kocyigit, Hypertens. Res. 36, 166 (2013). http://dx.doi.org/10.1038/hr.2012.156

38. M. Honda, Y. Yamada, M. Tomonaga, H. Ichinose, and S. Kamihira, Leuk. Res. 24, 461 (2000). http://dx.doi.org/10.1016/S0145-2126(00)00006-0

39. Hypertension study group, Bull. World Health Organ. 79, 490 (2001). 